\title{
Managing Refurbishment Projects Through Selection of Procurement System: The Case of Malaysia
}

\author{
Azlan Shah Ali ${ }^{*}$, Au Yong Cheong Peng ${ }^{1}$ and Susie Chieng Ling ${ }^{1}$
}

\begin{abstract}
The type of procurement method determines how the project would be managed. This is because project uncertainty could be found in the way that projects are awarded and how the construction project is managed into a system of contract. Procurement methods also influenced the time performance of construction projects. Time would be affected by the flow of project that was driven by different type of procurement method. However, it's still inconclusive to what extent that different types of procurement systems could affect the performance of refurbishment projects. This study conducted to identify types of procurement methods used in Malaysian refurbishment projects and what are the problems and difficulties encountered by contractor using different types of procurement systems. On top of that, the study also would examine relationship between challenges encountered by contractors using different types of procurements towards refurbishment projects performance. Triangulation technique was used in the study. 316 sets of closedended questionnaires were obtained from targeted respondents which included site agents, project engineer, contract administrator, contract manager and project manager who were working in various construction companies. From the questionnaire sent out, 268 questionnaires were found to be useful for data analysis, giving a final response percentage of $24.53 \%$. Semi-structured interview has been carried out with 15 contractors to validate the result. The findings shown that $54.3 \%$ of the projects were used traditional procurement systems, $39.9 \%$ using design and build, $4.3 \%$ using management procurement, $1.1 \%$ of the refurbishment project using turnkey system and $0.3 \%$ using built-operate-transfer (BOT) system. Refurbishment projects using traditional procurement systems were performing well compared to the others. Besides, out of seven contractor challenges variables (independent) which are cash flow and financial, communication with client and consultants, client decision making, frequent change order by client, insufficient or discrepancies of contract documents, material price escalation and skill, expertise and experience tested were significantly correlated with at least one performance variable (dependent). The findings would be useful for future references, especially to those stakeholders who involved in refurbishment projects in Malaysia.
\end{abstract}

Keywords: Malaysia, Procurement system, Performance, Refurbishment

\section{Introduction}

Compared to new build project, the refurbishment projects are more risky and complex, in which makes it more difficult to manage (Ali, 2008). A review of current practices in Malaysia shows different approaches to the refurbishment procurement

Centre for Construction, Building and Urban Studies (CeBUS)

Faculty of Built Environment, University of Malaya, Kuala Lumpur, Malaysia

*Corresponding author. 
systems. The introduction of different types of procurement systems has contributed to higher difficulties in managing refurbishment project under various circumstances (Ali et al., 2011).Hardcastle and Tookey (1998) also has highlighted that the refurbishment industry has been heavily criticized for its inefficient and ineffective procurement strategies and processes. The inefficient and ineffective procurement strategies and processes have been considered as a factor that has affected the industry's performance.

The different types of procurement system have different methods and process of designs and constructions. It described a different systems and a different organization structure in term of roles, responsibility and the authority of each members in the team. However, it's still uncertain on how far do the different types of procurement system have different methods, process and organization structure and how it can affect the performance of a refurbishment project in term of cost, time and quality. These problems and impacts have to be measured so that it can be used as a guide in selecting a better procurement system.

Therefore, it is essential to understand today's practice procurement method and to identify problems face by the contractor in using different types of procurement systems, and the impact of the problems towards project performance in term of cost, time and quality.

\section{The Growth of Refurbishment Projects}

Demands for refurbishment works are differ every year depending on the various factors that contribute to the growth of the projects. Figure 1 shows Total Project Value for Refurbishment projects in Malaysia from year 2004 to year 2011.

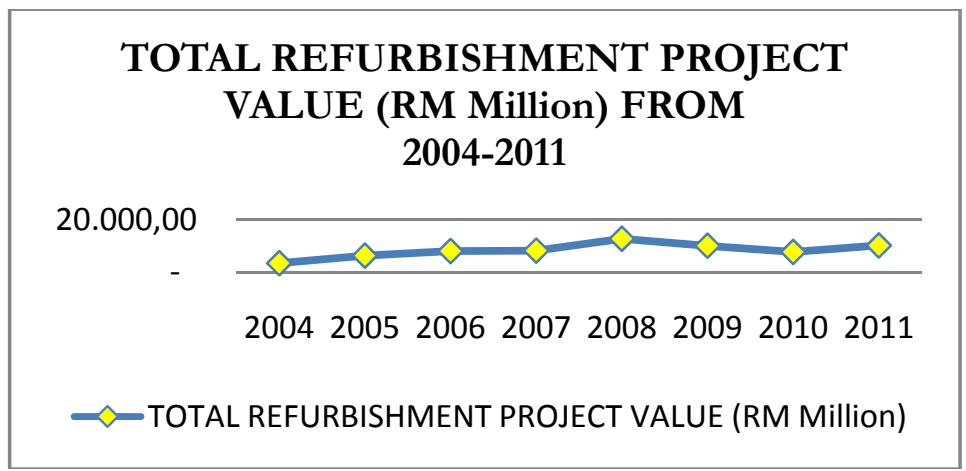

Figure 1: Total V alue for Refurbishment project from 2004-2011 (CIDB Statistic, 2006 - 2011)

Refurbishment Works are still demanded in Malaysian Construction Industry due to several factors. Rapid changes of technology used, change in building used, economic change and limited vacant land for new development shall be factors that induce to development of refurbishment project (Rahmat et al., 2003; Ali et al., 2009). More often than not, building refurbishment is initiated by physical deterioration and obsolescence, which includes change in technology, social, image, legal and environment. 


\section{Types of Procurement Systems}

There are numerous types or variations of project procurement systems being widely used in the refurbishment industry from the range from the traditional system to the many variations of "fast-tracking" systems such as turnkey, design and build, buildoperate-transfer and management contracting, (Rosli et al., 2006).

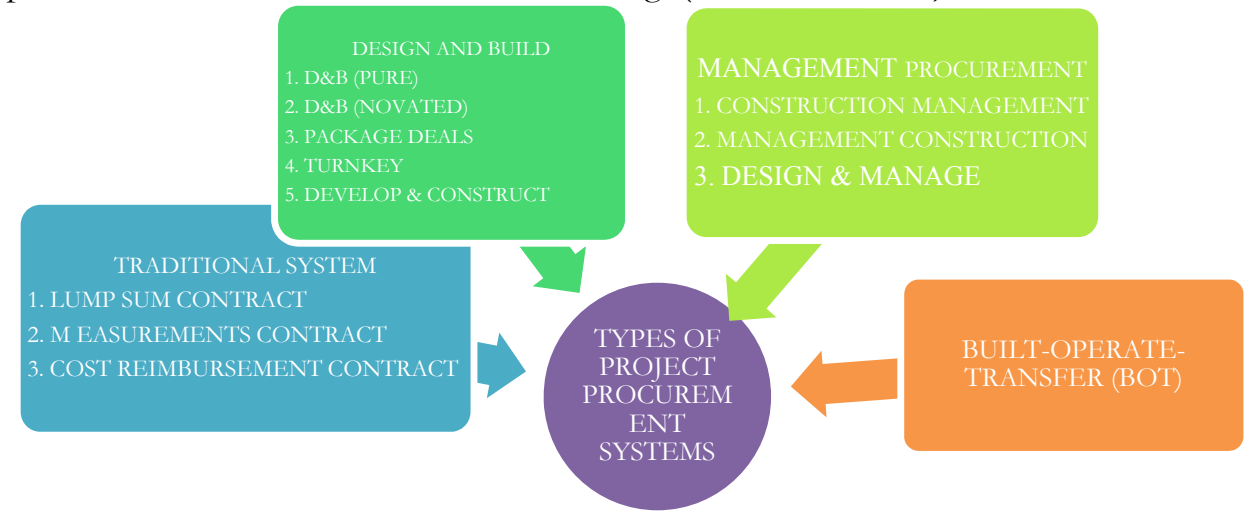

Figure 2: Types of Project Procurement Systems in Construction Industry

\subsection{Traditional System}

The traditional procurement system is predominant in the Malaysian construction industry and, until 1992 at least, able to satisfy its requirements (Masterman, 1992). It is characterized by the contractor not being responsible for the design or the documentation work (Goldfayl, 1999) and with a clear division between the design and construction process responsibilities (Rowlinson, 1999). The main advantages of using a traditional approach to procurement are produces lowest bid, assuring quality control and familiar in the industry whereby its disadvantages are builders not involved in design process, slower speed and potential adversarial (Peter et al., 2008).

\subsection{Design and Build System}

The term "Design and Build" refers to the procurement strategy that entails the contractor carrying out the work; the design works as well as the construction and completion of the work.The main advantages of using a design and construct approach to procurement are contractor act as single point of responsibility, Price Certainty, Effective communication and Multi-disciplinary approach and the disadvantages are higher costs, the limitation of competition in the public section, Difficulties in preparing an adequate and sufficiently comprehensive brief, requires early confirmation of concept designand absence of a bill of quantities (Peter et al., 2008).

\subsection{Management Procurement System}

Several variants of management procurement forms exist, which include; management contracting, construction management and design and manage. In the case of management contracting, the contractor has direct contractual links with all the works 
and a contractor is responsible for all construction work. In construction management, a contractor is paid a fee to professionally manage, develop a programme and coordinate the design and construction activities, and to facilitate collaboration to improve the project's constructability. The main advantages of using a management approach to procurement areenables improved coordination and collaboration, potential for time savings, roles, risks and responsibilities for all parties are clear and flexibility for changes in design The main disadvantages are proactive client is required, poor price certainty, client loses direct close time and information control required and client must provide a good quality brief to the design team (Peter et al., 2008):

\subsection{Built-Own-Operate-Transfer (BOOT)}

Developers use their own funding sources to build a public facility in return for the right to operate it and charge a fee for its use. At the end of an agreed period the facility may revert to the landholder. This type of contract focuses on final service delivery and relies upon the required performance standards being properly documented. Building contractors involved in this type of development are usually part of a consortium (Department of Infrastructure Building Services Agency, 1998). BOOT procurement system is less implemented in Malaysia refurbishment project. The main advantages of using these approaches is time and cost savings whereby the main disadvantages of BOOT procurement system are due to additional cost and inflexibility.From this chapter, it can be concluded that there are four main types of procurement systems which are traditional, design and build, management contract and BOOT systems. Different types of procurement systems have different characteristics and it serve a different way in affecting the refurbishment project performance.

\section{Difficulties Encounter by Contractor}

Over-due, over cost and poor quality construction today is frequently blamed on the procurement route selected. In reality serious problems can be attributed to the interaction of a whole series of smaller problems acting at once. Several researches and studies have been done by numerous researchers to identify challenges encounter by the contractor in managing construction works in design and build, traditional, contract management procurement and others. Primary amongst these problems is regarded as 'human aspects'. This is exemplified in construction today as a lack of common, shared purpose in a project leading towards a confrontational management style.

Figure 3 shows the common challenges encounter by Contractor in using different types of procurement method.

\subsection{Methodology}

The study approach incorporated triangulation techniques that combined both qualitative and quantitative approaches. The objective of employing a quantitative method is to minimize personal prejudice or bias and to ensure that the social reality would be presented as it is. It is expected to have true value, applicability, consistency and conformability (Guba and Lincoln, 1989). On the other hand, qualitative data refer to information gathered in a narrative through interviews, experience and observations 
(Sekaran, 2005).The combination of both research methods in a social science study could produce robust and valid findings at the end of the study. This is because the qualitative approach could complement results obtained from a quantitative approach, which would make it more reliable (Ali et al, 2009).

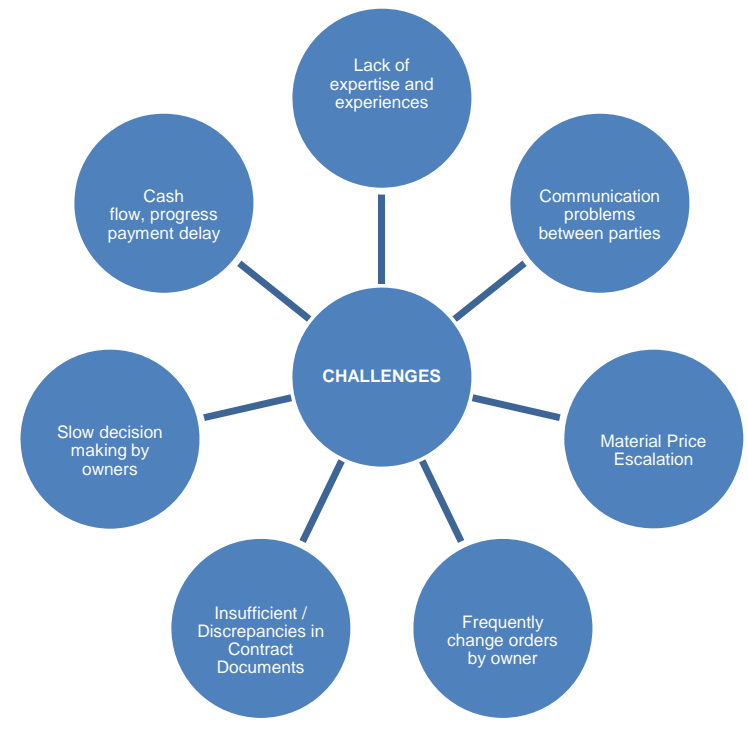

Figure 3: Difficulties and Problems Encounter by Contractor(Nubu and Issaka, 2008; Wellington and Mpendulo, 2008)

Four hundred and ten, 410 closed-ended questionnaires were obtained and received and the targeted respondents included site agents, project engineer, contract administrator, contract manager, project manager and other parties who are working in Construction Company; which three hundred sixty eight, 368 questionnaires were found to be useful for data analysis, giving a final response percentage of approximately 24.53 $\%$.Findings shows that almost $60 \%$ of the respondents were manager and director level and $63 \%$ of them had more than 10 years' experience in construction industries. This indicated the data collected from this survey are reliable. The data were analysed by using the Statistical Package for the social science (SPSS) software, version 17.0.

\section{Result and Discussion}

Figure 4 illustrated types of procurement systems used in Malaysian Refurbishment Projects. The result indicated that traditional systems is the most preferred system used in Malaysia with record of 54\%, followed by design and build with record of 40\%, Management procurement, 4\%, Turnkey System with record of 1\% and Built-Operate-Transfer BOT with record of $0.3 \%$.Besides, semi-structured interview shown that 12 out of 15 interviewees highlighted that traditional is the most preferred and suitable procurement system for Malaysia Refurbishment Projects if the contract value exceeded RM500,000.00.Turnkey, management and built-operate-transfer BOT system are less opted in Malaysian Refurbishment Projects as they are found not suitable. 
As pointed out by Peter et al. (2008), there are three types of traditional procurement method which is consist of lump sum contract, measurement contract and cost reimbursement/cost plus contract. Most of the interviewees mentioned that cost reimbursement/cost plus are the best option opted for refurbishment project due to the activities carried out are uncertain. For this contract, the contractors were being paid for an agreed fee to cover management, overheads and profits.

\section{Types of Procurement Systems in Malaysia}

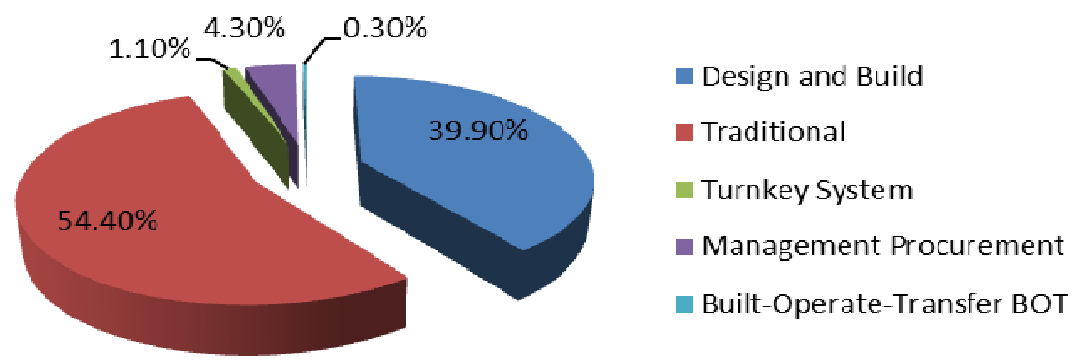

Figure 4: Types of Procurement Systems in Malaysia

Thomas et al. (2002) and Josephson and Lindstrom (2007) developed numerous parameters for measuring project performance which are cost, time and quality. The results shows most of the refurbishment projects using traditional system were completed within time, budget and quality (less complaint and NCR received) whereby refurbishment projects using design and build procurement system were completed within time. The results also shows that the refurbishment projects using BOT systems were completed with less non-compliance records (NCR).

Table 2: Performance of the refurbishment project in Malaysia

\begin{tabular}{|c|c|c|c|c|c|}
\hline $\begin{array}{l}\text { PROCUREMENT/PERFORMA } \\
\text { NCE }\end{array}$ & COST & TIME & $\% \mathrm{VO}$ & $\begin{array}{l}\text { COMP } \\
\mathrm{L}\end{array}$ & NCR \\
\hline TRADITIONAL SYSTEM & $p$ & $\hat{p}$ & $\vec{p}$ & $\vec{p}$ & $\dot{\gamma}$ \\
\hline DESIGN \& BUILD SYSTEM & & & & & \\
\hline TURNKEY SYSTEM & & & & & \\
\hline $\begin{array}{l}\text { MANAGEMENT CONTRACT } \\
\text { SYSTEM }\end{array}$ & & & & & \\
\hline $\begin{array}{l}\text { BUILT-OPERATE-TRANSFER, } \\
\text { BOT }\end{array}$ & & & & & \{ \\
\hline
\end{tabular}

Legend: - Witbin targeted (perform)

Traditional system is separated into different process with design and construction. The drawings, specification, and bill of quantities breakdown are provide by the client to the contractor during tender stage for ease of pricing. It also gives the client firmer and more competitive price because the design plus the complete working drawings have been fully developed and detailed out prior to tendering. It eliminates any design or construction ambiguity or uncertainty, which often causes the contractors to unnecessarily inflate the 
price. In the case where bill of quantities is used, the bidding tend to be more fair as such the project cost is lower. The system also has a better cost control (Masterman, 1996). In Design and Build and Turnkey procurement system, the cost to construct the refurbishment works is often higher than the traditional contracting system. This is due to the lack of design, specification detailing and absence of bill of quantities during tender and contractors are not considering the certain part of the work that are uncertain. This will consequently increase the construction cost and lead to the construction cost exceeded the budgeted cost. Furthermore, client is required to come out with a concept design at an early stage for design and build system. Undecided and incomplete concept committed to contractor at the early stage of the project will lead to higher frequent change order by client during construction stage.

In this study, independent variables refer to cash flow and finance, communication with consultant and client, decision making by client, frequent change order by client, insufficient and discrepancies in contract document, material price escalation and contractor skills, expertise and experience in handling refurbishment works whereas dependant variables refer cost variances, time variances, percentage of variation works, average numbers of complaints received and average numbers of non-compliance report. These analyses are used to achieve third objective of the present study, which is to examine relationship between problem and difficulties encountered by contractor using different types of procurements towards performance of Refurbishment Projects. The result was expected to show a positive correlation that would indicate that lesser difficulties face by the contractor in using different types of procurement systems is associated with higher project performance in Refurbishment Projects. The results of the correlation test are shown in Table 3.

Table 3. Correlation between contractor difficulties and project performance

\begin{tabular}{|c|c|c|c|c|c|}
\hline & $\begin{array}{l}\text { Cost } \\
\text { Variances }\end{array}$ & $\begin{array}{l}\text { Variation } \\
\text { Works (VO) }\end{array}$ & $\begin{array}{l}\text { Time } \\
\text { Variances }\end{array}$ & $\begin{array}{l}\text { Numbers } \\
\text { Complaint }\end{array}$ & $\begin{array}{l}\text { of Numbers of } \\
\text { NCR }\end{array}$ \\
\hline Cash Flow and Finance & $.361^{* *}$ & $.238^{* *}$ & $.132^{*}$ & $.119^{*}$ & .003 \\
\hline $\begin{array}{l}\text { Communication } \\
\text { Consultants and Client }\end{array}$ & $.276^{* *}$ & $.145^{* *}$ & $.183^{* *}$ & .120 & .063 \\
\hline Decision making by Client & $.195^{* *}$ & $.159^{* *}$ & $.166^{* *}$ & $.137^{* *}$ & -.063 \\
\hline $\begin{array}{l}\text { Frequent Change Order By } \\
\text { Client }\end{array}$ & $.294^{* *}$ & $.463^{* *}$ & .072 & $.142^{* *}$ & .101 \\
\hline $\begin{array}{l}\text { Insufficient/Discrepancies in } \\
\text { Contract Document }\end{array}$ & $.312^{* *}$ & $.318^{* *}$ & $.171^{* *}$ & $.151^{* *}$ & .028 \\
\hline Material price escalation & .112 & .011 & .005 & .004 & -.056 \\
\hline $\begin{array}{l}\text { Contractor Skill, Expertise } \\
\text { and Experience }\end{array}$ & $.229^{* *}$ & $.319^{* *}$ & .084 & .076 & .018 \\
\hline
\end{tabular}


Table 3 shows that generally more positive correlations were detected in the test. This indicates that contractor difficulties using different types of procurement influence it will be discussed as following:

\subsection{The Effect of Cash Flow and Finance towardsRefurbishment Project Performance}

Cash flow and financial is very important in determining project budget and actual cost. Cash inflow refers to the interim progress payment certified by client whereas cash outflow refers to the payment to sub-contractor and suppliers. In the event that cash out flow is more than cash inflow, it means that the cash flow is unhealthy and contractor will face difficulty in their financial. Contractor difficulties in managing cash flow and financial is found significant to the cost variances (actual project cost to target project cost). Late issuance of payment by client also will cause a huge cash flow problem and financial difficulty to Contractor. Unhealthy cash flow of a project in continuous manner will cause the contractor suffer for a loss as their monthly income is less than their monthly expenses. After the works has been completed on site, contractor has lesser bargaining power to claim for certain works that are not in the contract such as variation works. For instance, contractor may not being paid for the variation works as in client opinion; the works shall be price in the contract. As a result, contractor suffers for a loss in profits as payment for the sub-contractor and supplier have been make and the additional works are not able to claim from the client. Therefore, a good and healthy cash flow and financial is very crucial in ensuring the performance of project cost. Secondly, difficulties in cash flow and financial also found is significant with percentage of variation works. Due to unhealthy or poor cash flow and financial, contractor may work for extra miles to claim for the variation works. For instance, in design and build procurement system, contractor may claim certain of the works may not been price in the contract as the design intent and specification provided are not sufficient in tendering stage. In this case, it will prompt to high variation works. In the event that client refuses on that, contractor may come out with an alternative proposal with cheaper materials. This will cause poor quality and consequently lead to high defects and at the end of the day, client will make complaints on the works. The result also indicates that difficulties in cash flow and financial is significant with the average numbers of complaints received. Besides that, difficulties in cash flow and financial also found is significant with time variances. This finding result is supported by Abdul Kadir, et al. (2005) who mentioned that most contractors do not have an excellent financial standing and they are sub-contracting most of the works. The progress and speed of the refurbishment works is largely depend on the efficiency and availability of the workers. In the event late issuance payment from client, the contractor is facing difficulty in paying or not able to pay to the sub-contractor and suppliers. This indirectly will give an implication in stoppage of material delivery on site and sub-contractors tend to reduce speed and stop works at site.The result implies that a healthy cash flow and financial during the construction stage is required to ensure the contractor complete their job within determined budget, reduce percentage of variation works, assist contractor in payment certification which can avoid delay in the progress. Moreover, with the health financial will encourage contractor perform in term of quality. 


\subsection{The Effect of Communication With Consultants And Client Towards Refurbishment Project Performance}

Somogyi (1999) mentioned that the efficiency and effectiveness of the refurbishment process strongly depend on the quality of communication. For instance, improvement in the communication within the parties involved could reduce failure and smoothen of the project. In the semi-structured interview, half of the interviewees commented that failure in communication may cause actual project cost incurred higher than budgeted cost, delay in the project, increase of variation works and poor quality of the works. For instance, lack of communication between contractor and consultants and client may cause the information given are not convey among the parties and contractor may constructed the works on site without knowing the changes or instruction given. This will consequently cause argument and dispute between contractor and consultants which will lead to hacking and re-do and repeated works on site. As a result, the project will incur a higher cost as contractor required additional overhead and materials to do the hacking and reinstallation works. Due to this, the progress may delay as it will cause other elements or part of building could not be constructed / installed.In addition to the above, if the communication failure is part of the client fault, contractor is entitled to claim for variation works and client has to issue a variation order to contractor to adjust the contract sum. Other than that, in order to catch up the programme and to avoid any liquidated ascertained damage (LAD), contractor may accelerate the works without much concern on the quality. For instance, concreting of foundation must require 14 days for curing process; however, in order to catch up for the progress the contractor may start for the column works before the foundation is fully cured. This will consequently cause poor quality of the works and lead to major defect works in future. As a result, contractor may receive high numbers of complaints from the client due to the poor quality. This implies that effectiveness communication between client, consultant and contractor is crucial in order to ensure the project is completed within budget, time frame and quality. In addition, it may also reduce variation works and additional cost to client.

\subsection{The Effect of Client Decision Making Towards Refurbishment Project Performance}

Contractors' difficulties in client decision making is found significant to the cost variances (actual project cost to target project cost) and percentage of variation works. Client plays an important role in deciding and solves the issues and problems that may give a huge impact in cost, time and quality. In the semi-structured interview, 8 of the interviewees said that inexperience client in refurbishment works is not able to make a prompt decision on the problems highlighted whereas some of the clients make a wrong decision and it has caused increase in variation works as well as the costs. Although contractors are able to claim for the variation works due to the wrong and slow decision making, contractor is also suffering for certain cost that might not able to be claimed; which are overhead and machineries cost. For instance, slow decision making by client may cause idling of the machineries such as crane, generator set, compactor, and any others. Therefore, slow and wrong decision making not only will affect the additional works and cost to client but also will give impact to the contractor in terms profits and 
loss. In addition to that, contractor difficulties in client decision making also found significant with the time variances and number of complaint received. Slow and wrong decision making by client also will cause delay in the site progress. The delay of the decision may lead stop work or changes of sequence of construction for the Refurbishment Projects. As a result, contractor has to expedite and accelerate the work progress on site and this may affect the quality of the works. A right and fast decision making can prevent delay in a Refurbishment Project especially in fast track project. The result implies that a prompt and appropriate decision making by client during the construction stage is crucial to ensure and determine project performance in terms of cost, time and quality. Moreover, with the prompt and appropriate decision it can reduce percentage of variation works and cost to the client.

\subsection{The Effect of Frequent Change Order By Client Towards Refurbishment Project Performance}

Client needs for the projects are normally described through the briefing process. Designers will translate the client needs by producing a concept followed by detailed design. However, client frequently change their preferences throughout the design process and some clients are not able to prepare an adequate and sufficiently comprehensive brief. Without adequate and sufficient comprehensive brief, it is difficult for the designers to complete the design before work starts on site. The "theoretically completed" design, which keeps on changing, requires the designers to allocate an amount of provisional sum in the contract to cater for the uncertainty in the clients ${ }^{\text {ee }}$ needs. This result supports statements by Mitropoulos and Howell (2002) who stated that design changes were caused by clients changing their needs as the project progresses. This will result to additional variation works and costs to client. In addition, contractor facing difficulties in frequent change order by client is also significant with cost variances and average numbers of complaints received. Variation works due to changes of drawings may give a huge possibility in re-do and hacking works. Contractor with low productivity and poor in controlling labours and machineries will cause increase in man powers and machineries cost. Besides that, in the event contractor under-priced the items in the contract, any variation works shall be followed contract rate; which mean that contractor have to proceed to the variation works although there is no profits on works. As a result, contractor may use cheaper materials in order to cover the losses. This implies that frequent change order by client during construction works in progress will give impact to the project performance in terms of additional variation works, additional cost and poor quality.

\subsection{The Effect of Contract Difficulties In Insufficient And Discrepancies In Contract Document Towards Refurbishment Project Performance}

Contract documents consist of conditions of contract, specification, drawings and bill of quantities (BQ). As discussed earlier, Okoroh (1992) has pointed out that inadequacy the specifications from the architects make it difficult for contractors to define the exact scope of work in advance. Due to this, the planning and control of refurbishment works tend to be difficult in determining the actual time and cost of the works and in producing method statements and programmes (CIOB, 1987). As a result 
of poor planning and control, it will cause delay in the project, higher cost incurred by contractor due to wrong construction sequence, increase percentage of variegation works and additional cost to clients and resulting in poor quality of the works. Therefore, sufficient contract document such as detailing specification, drawings, and bill of quantities are required for ensuring the project is well perform in terms of cost, time and quality.

\subsection{The Effect of Contractor Difficulties without Skill, Expertise and Experience towards Refurbishment Project Performance}

The BRE (1990) cited that due to the condition of the existing building is uncertain; the responsibilities of the organizations and individuals on site cannot be clear-cut. Refurbishment work proceeds as a succession of technical problems requiring quick solutions. Frequently, techniques and methods of repair have to be uniquely developed for each building, eve $\mathrm{n}$ for similar building $\mathrm{s}$ built in the same period. Consequently, to plan and incorporate all uncertainties would be extremely difficult. Therefore, skill, expertise and experience contractors especially in design and build project is a must in ensuring the project can be perform within budget and lesser variation works. Skill and experience contractor able to come out with the design in cost savings and also reduce variation works by suggests better technical solutions. The correlation test results in Table 3 indicate that there are significant correlations between the contractor difficulties in using different types of procurement systems variables and the Refurbishment Project performance variables. Seven out of seven contractor difficulties variables tested were correlated with at least one Refurbishment Project performance variable.

\section{Conclusion}

The results obtained from the questionnaire surveys and semi-structured interview, it's concluded that traditional procurement systems are the most preferred system used in Malaysia Refurbishment projects, then followed by design and build. The findings also shows that traditional procurement systems is the most suitable to be used in refurbishment project with contract value more than RM500,000.00 due to its uncertainty. Management procurement, Turnkey system and built-operate transfer, BOT are less used in refurbishment project. In addition to that, Seven out of seven contractor difficulties variables (independent) tested were correlated with at least one Refurbishment Project performance variable (dependent).

\section{References}

Abdul Kadir, M. R., Lee, W. P., Jaafar, M.S., Sapuan, S.M., \& Ali, A.A.A. (2005). Factors affecting construction labour productivity for Malaysian residential projects. Structural Survey, Vol. 23 Iss: 1, pp. $42-54$

Ali, A. S., Rahmat, I., \& Hassan, H. (2008). Involvement of key design participants in refurbishment design process, Facilities. Vol. 26 No. 9/10, pp 389-400 
Ali, A.S., NorhanimZakaria\&Adi-IrfanChe-Ani (2011). The Effect of Procurement System towards the Performance of RefurbishmentWorks:Faculty of Built Environment, University of Malaya, Kuala Lumpur, Malaysia Conference

Ali, A.S., SyahrulNizamKamaruzzaman, \& Hafez Salleh (2009).The characteristics of refurbishment projects in Malaysia. Facilities Vol. 27 No. 1/2, pp. 56-65

British Research Establishment (1990). Assessing traditional housing for rehabilitation. HMSO: London, UK.

Chartered Institute of Building (CIOB) (1987). Code of Estimating Practice Supplement One: Refurbishment and Modernization. CIOB: Ascot.

DETR (1998). The Report of the Construction Industry Task Force: Rethinking Construction. The Egan Report, HMSO.

Goldfayl, G. (1999). Construction Contract Administration. Victoria: Deakin University Press.

Guba, E.G., \& Lincoln, Y.S. (1989).Fourth generation evaluation. Newbury Park, CA.

Hardcastle C. \& J.E. Tookey, (1998).Re-engineering the Building Procurement Decision Making Process. Department of Building and Surveying, Glasgow Caledonian University: Cobra 1998 Conference

Josephson, P. E. and Lindstrom, J. (2007).Measuring Performance in Construction Projects. Proceeding of the CIB World Building Conference on Construction for Development, Cape Town, South Africa, 14 - 18 May 2007, pp 383-394

Masterman, J.W.E. (1992). An Introduction to Building Procurement Systems. London: E \& FN Spon.

Masterman J W E (1996). Building Procurement Systems: An Introduction, E \& FN Spon, London

Nuhu Braimah \& Issaka Ndekugri. (2008). Factors influencing the selection of delay analysis methodologies. International Journal of Project Management , 26, 789-799.

Okoroh, M.C. (1992). Knowledge-based decision support system for the selection and appointment of subcontractors for building refurbishment contracts. PhD thesis, Loughbourough University, Loughbourough.

Peter D., Peter L., David B., Geoff W., Robert L. (2008). Capital Works Procurement: The Selection of a Building Procurement Method. Project Affiliates Curtin University of Technology Western Australia Department of Housing \& Work Royal Melbourne Institute of Technology Research Program: Deliver and Management of Built Assets

Rahmat, I., Torrance, V.B., \& Ezanee, A.H. (2003). Refurbishment cycles and the management of refurbishment projects. UiTM Research Centre, Shah Alam, Selangor, Malaysia.

Rosli Abdul Rashid, Ismail Mat Taib, Wan Basiron Wan Ahmad, Md. AsrulNasid, Wan Nordiana Wan Ali \&ZainabMohdZainordin (2006). Effect of procurement systems on the performance of construction projects.Department of Quantity Surveying, Faculty of Built Environment, UniversitiTeknologi Malaysia.

Rowlinson, S. (1999).A Definition of Procurement Systems. In Procurement Systems: A Guide to Best Practice in Construction (ed). 27-51. London: E \& FN Spon.

Sekaran, U. (2005). Research Methods For Business: A Skill Building Approach. 4 ed. Carbondale: John Wiley \& Sons, Inc.

Somogyi, A. (1999) The Role of Project Management. Report unpublished.

Thomas, S.R., Macken, C.L., Chung, T. H., and Kim, I. (2002).Measuring the Impact of the Delviery System on Project Performance: Deisgn-Build and Design-Bid-Build NIST GCR 02- 840. Construction Industry Institute. Austin.

Wellington D.T.\& Mpendulo M. (2008). Current challenges and problems facing small and medium size contractors in Swaziland. African Journal of Business Management, 2 (5). 